IDENTIFICAREA BACTERIILOR DIN GENUL SALMONELLA SPP. ÎN PRODUSELE AVICOLE ȘI IMPACTUL ACESTORA PENTRU SĂNĂTATEA PUBLICĂ

\author{
Olga JUNCU, Nicolae STARCIUC, Natalia OSADCI, Tatiana ANTOHII
}

Universitatea Agrară de Stat din Moldova, Republica Moldova

Autor corespondent: Nicolae Starciuc, e-mail: n.starciuc@asm.md

DOI: $10 / 38045 /$ ohrm.2021.2.13

CZU: 614.31:637.075:579.842.14

Keywords: Salmo- IDENTIFICATION OF SALMONELLA SPP. STRAINS IN POULTRY PRODUCTS nella, poultry, meat, egg, serotype.

\title{
AND THEIR IMPACT ON PUBLIC HEALTH
}

Introduction. Poultry meat and eggs represent a risk of contamination with zoonotic bacterial agents. This requires permanent laboratory monitoring throughout the production chain segment.

Material and methods. The research material consisted of samples retrieved from poultry carcasses and eggs for current consumption. There were examined 80 samples of eggs and 110 samples of poultry carcasses.

Results. S. Gallinarum, S. Enteritidis and S. Infantins serotypes were isolated in $12.7 \%$ of samples out of 110 examined carcasses, whereas S. Gallinarum, S. Dublin și S. Typhimurium serotypes were detected in $6.25 \%$ of 80 egg samples.

Conclusions. Bacteriological research on poultry carcasses and eggs showed the presence of pathogenic serotypes of Salmonella spp., which is a major risk to public health.

Cuvinte cheie: Salmonella, păsări, carne, ouă, serotipuri.
Introducere. Carnea și ouăle de pasăre prezintă un risc crescut de contaminare cu agenți bacterieni zoonotici. În acest context, este necesară monitorizarea de laborator permanentă, pe întregul lant de producție.

Material și metode. Materialul de cercetare a fost constituit din probe de la carcasele de pasăre și ouă de consum curent. Au fost examinate 80 probe de ouă și 110 probe de la carcasele de pasăre.

Rezultate. Din 110 probe de carcase examinate, la 12,7\% au fost izolate serotipurile S. Gallinarum, S. Enteritidis și S. Infantins, iar din 80 de probe de ouă, la 6,25\% au fost izolate serotipurile S. Gallinarum, S. Dublin și S. Typhimurium.

Concluzii. Cercetările bacteriologice asupra carcaselor de pasăre și ale ouălor au demonstrat prezența erotipurilor patogene de Salmonella spp., cu risc major pentru sănătatea publică. 


\section{INTRODUCERE}

În prezent, avicultura reprezintă una dintre cele mai importante ramuri ale sectorului zootehnic din Republica Moldova, care pe parcursul mai multor ani a devenit cea mai dezvoltată, industrializată și cea mai dotată tehnologic, în comparație cu celelalte ramuri. În acest context, produsele avicole și-au câștigat poziţii prioritare, în rândul alimentelor de proveniență animalieră, datorită calităţilor nutritive ce le posedă, precum și costurilor de producere reduse față de alte alimente de aceeași origine. Pe lângă factorii de importanță majoră în avicultură, care contribuie la dezvoltarea intensivă a ramurii, precum producţia de furaje combinate, centrele de selecție și tehnologiile de întreținere, măsurile sanitar-veterinare și de prevenire a bolilor infecțioase, au un rol esențial $(1,2,3)$. Actualmente este imposibil de a produce carnea și ouăle de pasăre, fără o metodologie bine fundamentată și implementată, de monitorizare și prevenire a bolilor infecțioase (4, 5).

Ouăle și carnea de pasăre sunt caracterizate ca fiind produse cu valoare nutritivă înaltă. Datorită calităților organoleptice și dietetice, specifice ouălor și cărnii de pasăre, aceste produse corespund major cerințelor alimentare actuale, fiind în permanență solicitate de către consumatori. Totodată, întrebuințarea acestor produse reprezintă și un risc major de contaminare cu agenți bacterieni de ordin zoonotic, cum ar fi: Salmonella, E. coli, Campilobacter, Listeria etc., care necesită monitorizare epidemiologică, clinică, morfopatologică și de laborator permanentă, în toate segmentele lanțului de producere, până la consumator $(6,7,8)$.

Reieșind din cele menționate, scopul cercetărilor noastre a fost de a stabili prezența și diversitatea formelor de bacterii din genul Salmonella spp., în carnea și ouăle de pasăre, din unele puncte de comercializare a produselor de origine animală.

\section{MATERIAL ȘI METODE}

Cercetările au fost efectuate în cadrul Departamentului II al Facultății de Medicină Veterinară, de la Universitatea Agrară de Stat din Republica Moldova și în laboratorul Metode de Combatere şi Profilaxie a Maladiilor, din cadrul Institutului Știinţifico-Practic de Biotehnologii în Zootehnie şi Medicină Veterinară din Republica Moldova. Serotipizarea izolatelor de Salmonella spp. a fost efectuată la Centrul Republican de Diagnostic Veterinar din Chișinău.

Materialul de cercetare a fost constituit din probe de la carcasele de pasăre și ouăle de consum curent, provenite de la unele unități de producere a cărnii și ouălor de pasăre, precum și produse avicole din rețeaua de comercializare a produselor alimentare din cadrul Pieții Agricole Centrale din Chișinău.

Izolarea și identificarea bacteriilor din genul Salmonella Spp. a fost efectuată conform metodei SM EN ISO 6579-1:2017 - Microbiologia lanțului alimentelor, metoda orizontală pentru detectarea, numărarea și tipizarea serologică a bacteriilor de genul Salmonella Spp. Probele au fost supuse testelor microbiologice clasice, utilizând metodele de lucru din standardele naționale în vigoare, iar confirmarea s-a realizat cu ajutorul testelor „Microbact", conform instrucțiunii de la producător, în paralel realizându-se și detecția tulpinilor Salmonella Typhimurium ATCC 14028. Pentru izolarea și identificarea bacteriilor au fost utilizate medii de cultură de îmbogățire, obișnuite, selective, speciale (agar XLD, Brilliance Salmonella Agar), chituri cu seruri monovalente pentru serotipizarea bacteriilor din genul Salmonella spp. și seturi pentru colorarea frotiurilor. Au fost prelevate și examinate, în condiții de laborator, 80 probe de ouă și 110 probe de la carcasele de pasăre.

\section{REZULTATE}

Investigațiile bacteriologice au demonstrat o creștere evidentă a coloniilor de Salmonella spp., din toate probele prelevate de la carcasele de pasăre, fapt ce demonstrează o prezență permanentă a serotipurilor de Salmonella, pe produsele din carne de pasăre. Ulterior, după procedura de îmbogățire a culturilor bacteriene izolate și efectuarea procedurii de serotipizare, s-a stabilit prezența unor serotipuri patogene de Salmonella spp. (tab. 1).

Conform rezultatelor obținute, putem menționa că din cele 110 probe examinate au fost identificate serotipuri patogene de Salmonella spp. la 14 probe, respectiv 12,7\%, fiind izolate în special Salmonella Gallinarum, Salmonella Enteritidis și Salmonella Infantis $(4,7)$.

Cel mai înalt procent de contaminare cu bacterii din genul Salmonella s-a dovedit a fi la întreprin- 
derile avicole SRL "Procolnis" și GŢ" Goroșenco Angela".

În urma investigațiilor bacteriologice efectuate la ouăle de consum, colectate de la 8 întreprinderi avicole producătoare de ouă de consum curent din republică (tab. 2), s-a constatat că la $85 \%$ din ouăle examinate, pe mediile de cultură au crescut colonii de Salmonella spp., iar după efectuarea serotipizării, din 80 de probe cercetate, la 5 probe au fost identificate serotipuri patogene de Salmonella spp.; precum-Salmonella Gallinarum, Salmo nella Dublin, Salmonella Typhimurium, care au constituit 6,25\% din numărul probelor cercetate. Cel mai înalt procent de contaminare s-a dovedit a fi la întreprinderea avicolă SRL "Dant Agro" (2, 8).

Tabelul 1. Probe prelevate de la producătorii cărnii de pasăre.

\begin{tabular}{llccc}
\hline $\begin{array}{l}\text { Nr. } \\
\text { d/o }\end{array}$ & Denumirea întreprinderii & $\begin{array}{c}\text { Nr. de probe } \\
\text { prelevate }\end{array}$ & $\begin{array}{c}\text { Numărul de probe } \\
\text { pozitive cu serotipuri } \\
\text { Salmonella spp. }\end{array}$ & $\begin{array}{c}\text { Proporția probelor } \\
\text { pozitive, \% }\end{array}$ \\
\hline $\mathbf{1}$ & ÎI „Valcovschii Iurii”, & 12 & 2 & 16,6 \\
\hline $\mathbf{2}$ & GT „Marandici Serghei” & 10 & 0 & 0 \\
\hline $\mathbf{3}$ & SRL “Dobrovolischii”, & 10 & 2 & 20,0 \\
\hline $\mathbf{4}$ & GT „Goroșenco Angela” & 12 & 3 & 25,0 \\
\hline $\mathbf{5}$ & SRL „Viamar”, & 12 & 1 & 8,3 \\
\hline $\mathbf{6}$ & SRL „Genevis Grup” & 10 & 1 & 10,0 \\
\hline $\mathbf{7}$ & SA „Floreni” & 10 & 1 & 10,0 \\
\hline $\mathbf{8}$ & SRL „Margaritar Impex” & 10 & 2 & 20,0 \\
\hline $\mathbf{9}$ & ÎI „Poperecnaea Elena” & 12 & 0 & 0 \\
\hline $\mathbf{1 0}$ & SRL “Procolnis” & 12 & 2 & 25,0 \\
\hline & Total & 110 & 14 & $\mathbf{1 2 , 7}$ \\
\hline
\end{tabular}

Tabelul 2. Probe de ouă prelevate de la producătorii ouălor de consum curent.

\begin{tabular}{llccc}
\hline $\begin{array}{c}\text { Nr. } \\
\text { d/o }\end{array}$ & $\begin{array}{c}\text { Denumirea întreprinderii } \\
\text { avicole }\end{array}$ & $\begin{array}{c}\text { Nr. de probe } \\
\text { prelevate }\end{array}$ & $\begin{array}{c}\text { Numărul de probe } \\
\text { pozitive cu serotipuri } \\
\text { de Salmonella spp. }\end{array}$ & $\begin{array}{c}\text { Proporția probelor } \\
\text { positive, \% }\end{array}$ \\
\hline $\mathbf{1}$ & SRL „Pasărea argintie” & 10 & 0 & 0 \\
\hline $\mathbf{2}$ & I.M. PB Nord" SRL, & 10 & 1 & 10,0 \\
\hline $\mathbf{3}$ & SRL “Intervetcom” & 10 & 0 & 0 \\
\hline $\mathbf{4}$ & SRL “Redi Agro" & 10 & 1 & 10,0 \\
\hline $\mathbf{5}$ & SRL “Dant Agro" & 10 & 2 & 0 \\
\hline $\mathbf{6}$ & SRL “Solar Nord" & 10 & 0 & 0 \\
\hline $\mathbf{7}$ & SA “Floreni” & 10 & 0 & 10,0 \\
\hline $\mathbf{8}$ & SRL "Avicola Rișcani” & 10 & 1 & $\mathbf{6 , 2 5}$ \\
\hline & Total & 80 & 5 & \\
\hline
\end{tabular}

Probele prelevate de la carcasele de pasăre în greutate de $25 \mathrm{~g}$ fiecare, au fost inoculate în 225 $\mathrm{ml} \mathrm{APT} \mathrm{(fig.} \mathrm{1)} \mathrm{și} \mathrm{puse} \mathrm{la} \mathrm{incubare,} \mathrm{la} 37 \pm 10^{\circ} \mathrm{C}$, timp de $24 \pm 3 \mathrm{~h}$ (agar XLD si Brilliance Salmonella Agar). Ulterior, s-au selectat coloniile tipice şi s-a marcat poziţia lor pe versoul plăcii. După incubare, din cultura obţinută în bulion RVS, s-a inoculat pe suprafaţa plăcii Petri, care conţine primul mediu selectiv de izolare (agar XLD), pentru a obţine colonii izolate. Se procedează la fel cu bulion MKT, la cel de-al doilea mediu selectiv (Brilliance Salmonella Agar).

După incubarea mediilor de cultură (fig.2), au fost selectate coloniile cu dezvoltare tipică. Coloniile cu structură morfologică tipică de Salmonella, crescute pe mediul XLD, au centrul negru şi zonă transparentă luminoasă, de culoare roșiatică (fig. 4); iar pe mediul Brilliance Salmonella Agar, coloniile de Salmonella spp. sunt de culoare violetă (fig. 3).

Serotipurile de Salmonella H2S-negative, pe mediul XLD, sunt de culoare roz, cu centru închis. Salmonella lactozo-pozitivă, pe XLD este galbenă, cu sau fără centru negru.

După incubarea mediilor de cultură (fig.2), au fost 
selectate coloniile cu dezvoltare tipică. Coloniile cu structură morfologică tipică de Salmonella, crescute pe mediul XLD, au centrul negru şi zonă transparentă luminoasă, de culoare roșiatică (fig. 4); iar pe mediul Brilliance Salmonella Agar, coloniile de Salmonella spp. sunt de culoare violetă

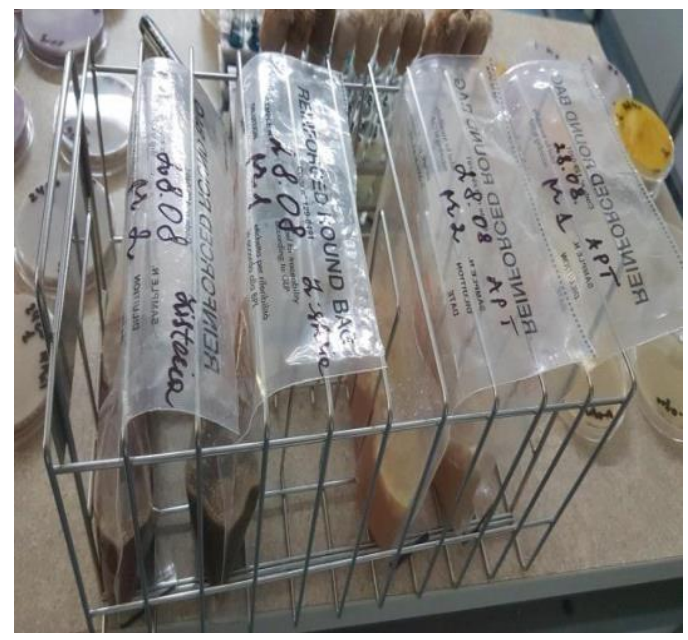

Figura 1. Procedura de îmbogățire a probelor (Salmonella Agar).

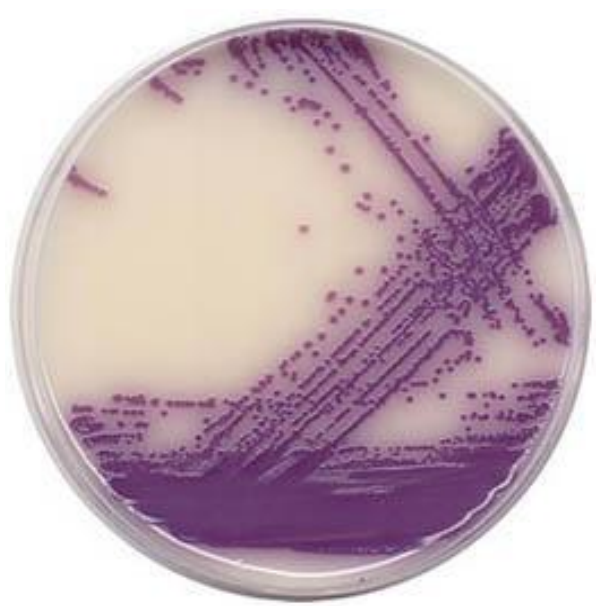

Figura 3. Brilliance Salmonella Agar colonii violete de Salmonella.

Pentru confirmarea biochimică și serologică au fost folosite culturi pure. Din culturile de colonii au fost pregătite frotiuri, ulterior examinate la microscopul optic cu imersie (ob.10x100). Prezența și structura morfologică a bacteriilor din genul Salmonella spp. sunt prezentate în Figura 5, unde sunt plasate în câmpul microscopului ca bastonașe, în formă de grămezi sau separate, cu capetele rotunjite.

Coloniile de Salmonella spp. au fost serotipizate (fig. 3).

Serotipurile de Salmonella H2S-negative, pe mediul XLD, sunt de culoare roz, cu centru închis. Salmonella lactozo-pozitivă, pe XLD este galbenă, cu sau fără centru negru.

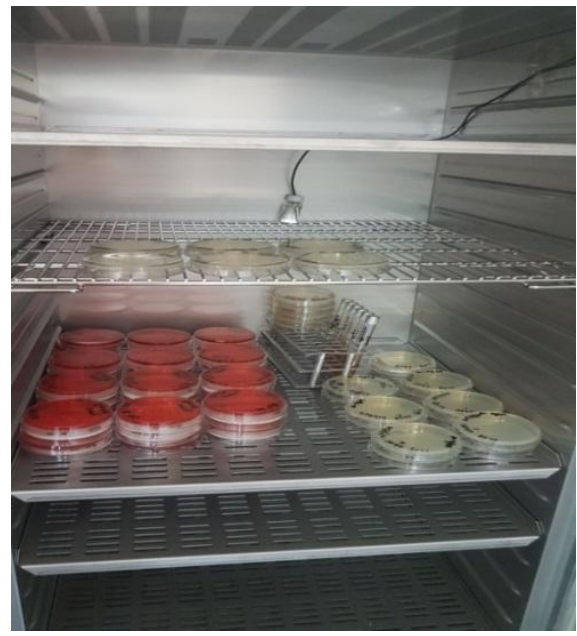

Figura 2. Incubarea la $37 \pm 1{ }^{\circ} \mathrm{C}$, timp de $24 \pm 3 \mathrm{~h}$ (agar XLD si Brilliance).

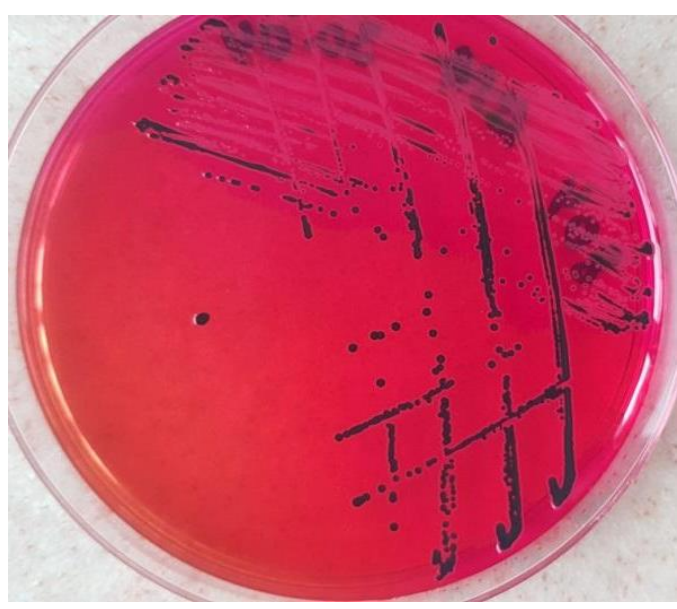

Figura 4. Coloniile tipice de Salmonella, pe medii XLD, cu centrul negru şi zonă transparentă de culoare roșiatică.

folosind serurile monovalente (fig. 6).

\section{DISCUȚII}

Necesitatea acestui studiu a reieșit din faptul că, în mod sistematic, la efectivele de păsări ouătoare, la necropsia cadavrelor se constata un procent semnificativ de peritonite viteline, precum și alte afecțiuni cum ar fi salpingite, ovarite, enterocolite, leziuni care de regulă reprezintă modificări caracteristice salmonelozei aviare $(2,5)$. 


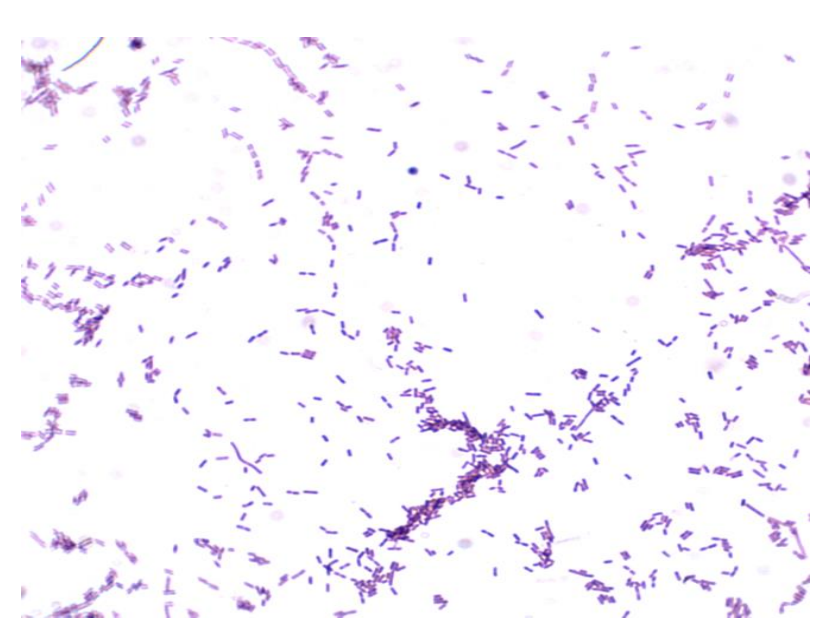

Figura 5. Bacterii din genul Salmonella spp.

(Bastonase gr -)

Prezența păsărilor contaminate cu bacterii din genul Salmonella spp. crește și riscul de transmitere a acestor bacterii, în special a serotipurilor patogene, prin produsele avicole, precum carnea și ouăle de consum curent, facilitând astfel contaminarea consumatorilor și apariția riscului de toxiinfecții cu Salmonella spp. la oameni (1).

Cercetările efectuate în scopul monitorizării prezenței și diversității serotipurilor patogene de bacterii din genul Salmonella, au confirmat faptul că în produsele avicole sunt prezente serotipuri patogene de Salmonella spp. Din numărul total de probe de carne de pasăre examinate (110), în 12,7 $\%$ dintre acestea au fost izolate serotipuri patogene de Salmonella spp., în special Salmonella Gallinarum, Salmonella Enteritidis și Salmonella Infantins, iar în cazul efectuării serotipizării colonii-

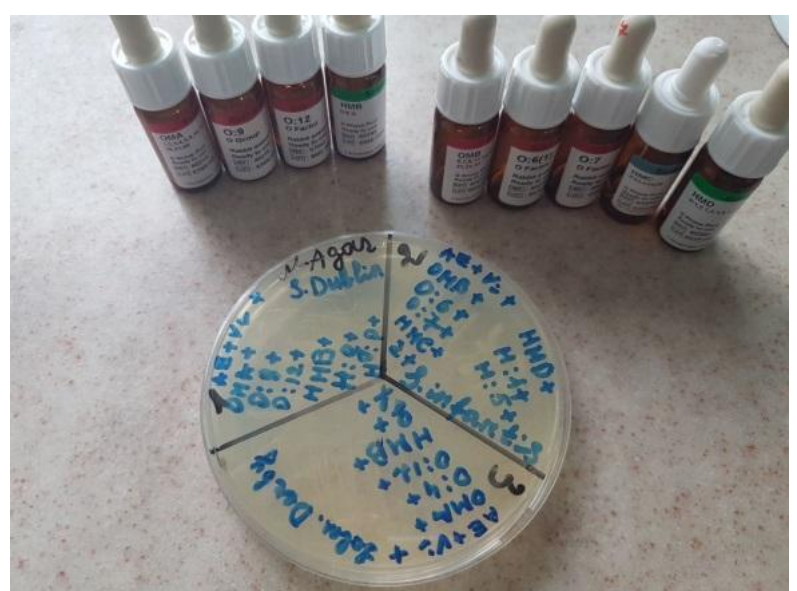

Figura 6. Mediile de cultură și serurile specifice monovalente.

lor de bacterii din genul Salmonella spp., izolate de la ouăle de consum curent, din 80 de probe cercetate, la 5 probe $(6,25 \%)$ au fost identificate serotipuri patogene de Salmonella spp., precum: Salmonella Gallinarum, Salmonella Dublin, Salmonella Typhimurium $(1,7)$.

Rezultatele obținute în cadrul cercetărilor noastre confirmă faptul că, supravegherea epidemiologică a salmonelozei aviare necesită respectarea, cu strictețe, a tuturor măsurilor sanitar-veterinare, pe tot lanțul de producție, sacrificare, păstrare, transportare și comercializare a produselor avicole, precum și monitorizarea microbiologică a produselor avicole, în special în perioada de comercializare, în vederea minimizării riscului de consum al produselor avicole, contaminate $\mathrm{cu}$ bacterii din genul Salmonella, de către oameni (8).

\section{CONCLUZII}

1. În absența unui complex de măsuri sanitar-veterinare și curativ-profilactice, în cadrul întreprinderilor avicole, salmoneloza aviară rămâne în continuare o problemă importantă pentru sănătatea efectivelor de păsări, provocând pierderi economice considerabile, precum și riscuri majore pentru sănătatea publică.

2. Cercetările bacteriologice asupra carcaselor de pasăre au demonstrat că la $12,7 \%$ din numărul total de probe examinate au fost depistate serotipuri patogene de Salmonella spp., cu predominanța serotipurilor Salmonella Gallinarum, Salmonella Enteritidis și Salmonella Infantins.

3. Din numărul total al probelor de ouă examinate, serotipuri patogene de Salmonella spp., precum Salmonella Gallinarum, Salmonella Dublin și Salmonella Typhimurium, au fost identificate la 6,25\% din probele examinate.

\section{CONFLICT DE INTERESE}

$\mathrm{Nu}$ exista conflicte de interes.

\section{REFERINTE}

1. Antunes P, Mourão J, Campos J, Peixe L. Salmonellosis: the role of poultry meat. Clin. Microbiol.
Infect. 2016;22(2):110-121.

2. Mamber SW, Mohr T, Barlow K, Bronstein PA, Leathers C, Clinch N. Occurrence of Salmonella in Ready-to-Eat Meat and Poultry Product Samples from U.S. Department of Agriculture-Regulated Producing Establishments. 
Pork Barbecue Products, from 2005 to 2012. J. Food. Prot. 2018;81(10):1737-1742.

3. Fall-Niang NK, Sambe-Ba B, Seck A, Deme SN, Wane AA, Bercion R, Alambedji-Bada R, GassamaSow A. Antimicrobial Resistance Profile of Salmonella Isolates in Chicken Carcasses in Dakar, Senegal. Foodborne Pathog. Dis. 2019;16(2):130.

4. Waldman J, Souza MN, Fonseca ASK, Ikuta N, Lunge VR. Direct detection of Salmonella from poultry samples by DNA isothermal amplification. Br Poult. Sci. 2020;61(6):653-659.

5. Jibril AH, Okeke IN, Dalsgaard A, Kudirkiene E, Akinlabi O, Bello M.B, Olsen JE. Prevalence and risk factors of Salmonella in commercial poultry

Date of receipt of the manuscript: 22/02/2021

Date of acceptance for publication: 21/03/2021 farms in Nigeria. PLoS One. 2020;15(9):12381248.

6. Grant A, Parveen S, Schwarz J, Hashem F, Vimini B. Reduction of Salmonella in ground chicken using a bacteriophage. Poult. Sci. 2017;96(8):28452852.

7. Kumar Y, Singh V, Kumar G, Gupta NK, Tahlan AK. Serovar diversity of Salmonella among poultry. Indian J. Med. Res. 2019;150(1):92-95.

8. Williams MS, Ebel ED, Saini G, Nyirabahizi E. Changes in Salmonella Contamination in Meat and Poultry Since the Introduction of the Pathogen Reduction and Hazard Analysis and Critical Control Point Rule.v J. Food. Prot. 2020; 83(10):1707-1717. 